\title{
Analysis and Characterization of Ultra High Molecular Weight Polyethylene (UHMWPE) subjected to reciprocating sliding and nanoidentation tests.
}

Tomas De la Mora ${ }^{1}$, Noé López Perrusquia ${ }^{2}$, Marco Antonio Doñu Ruiz ${ }^{2}$, Ernesto D. García Bustos ${ }^{3}$, Martín Flores Martínez ${ }^{3}$ and Israel Becerril Rosales ${ }^{4}$

${ }^{1}$ Tecnológico de Estudios Superiores de Jocotitlan, Jocotitlán Estado de México, Distrito Federal, Mexico, ${ }^{2}$ Universidad Politecnica del Valle de México, Tultitlan, Distrito Federal, Mexico, ${ }^{3}$ Universidad de Guadalajara, Guadalajara, Jalisco, Mexico, ${ }^{4}$ Tecnológico de Estudios Superiores de Jocotitlan, Jocotitlán Estado de México, Mexico

Ultra-high molecular weight polyethylene (UHMWPE) has been used in orthopedics as one of the materials for artificial joints in knee, hip and vertebral prostheses. The implanted joints are designed so that the metal articulates against the polymeric material. However, the main problem of knee prostheses is the lifetime of their components made of UHMWPE due to premature wear caused by friction, this being the most common inducer of osteolysis in joint prostheses [1]. The coefficient of friction, wear characteristics were studied using a reciprocating sliding tribometer and the modulus of elasticity was obtained by nanoidentation tests.

A UHMWPE cylinder type GUR® 1020 with a diameter of $30 \mathrm{~mm}$ was used, and $8 \mathrm{~mm}$ thick specimens were machined. The material was provided by the prosthesis manufacturer Trauma Mexico. The wear tests were performed with a CETR reciprocating motion equipment as shown in Figure 1a, under the ASTM G133-10 Standard [2]. Figure 1b shows a flat specimen and a $10 \mathrm{~mm}$ diameter spherical pin of $316 \mathrm{~L}$ stainless steel, which slides over the specimen at a speed of $30 \mathrm{rev} / \mathrm{min}$. A normal load of 10, 20 and 30 Newton, sliding time of 1800 seconds, stroke length of $30 \mathrm{~mm}$, frequency of $1 \mathrm{~Hz}$ oscillation, test temperature of $26 \pm 2{ }^{\circ} \mathrm{C}$, no lubricant and atmospheric environment (relative humidity $\mathrm{RH}$ ) between 25 and 30\% were applied (see Figure 1a). The friction coefficient tests were performed with $316 \mathrm{~L}$ steel material ball [3]. Afterwards, the wear surface was analyzed by means of an Optical Microscopy (OM) using ZEISS Axio Vert.A1. The modulus of elasticity was also evaluated before the wear test with an ultra micro Hardness Tester DUH211s, with a load of $2.0 \mathrm{mN}$; performing 30 tests, 15 horizontal and 15 vertical at a distance of $15 \mu \mathrm{m}$ between them as shown in Figure 1d.

The graphs of the coefficient of dynamic friction (COF) are shown in Figure 1c showing a uniform behavior for all test conditions. The COF values are quite homogeneous with a value of $0.099 \pm 0.001$. In all cases of the different loads, the COF reached steady state values a few seconds after the beginning of the test. From the presented diagram it can be observed that the load increase did not show significant influence on the COF. The value of the dry friction coefficient obtained is similar to that reported by other authors for the material used [4,5].

The surface micrographs show wear grooves generated by the film of the softer material being transferred to the harder material, in this case transfer from the polymer to the metal occurs. If the polymer film is removed from the metal surface and new transfer films are formed and removed, the rate of wear increases. If, on the other hand, the film remains permanently attached to the metal surface, the polymer wear rate decreases and the contact changes from metal-polymer to polymer-polymer, which can lead to increased 
friction [6]. The results show in the cases of $20 \mathrm{~N}$ and $30 \mathrm{~N}$ load, a groove is clearly observed on the soft surface of the UHMWPE by plastic deformation due to the hardness of the 316L steel ball surface, exceeding the shear strength of the material, as seen in Figure $2 \mathrm{a}$ and $2 \mathrm{~b}$, also tearing or fragmentation of the polyethylene (pitting) is observed in the areas in red circle. The transverse length of the wear track was determined by planimetry to observe the change in track width depending on the loads used, as shown in Figure 2a. It can also be observed in the optical micro-graphs the existence of elastic hysteresis formation produced in viscoelastic materials as shown in his study by Tabor [7], which consists of loss of material and energy in the grooves or grooves (see Figure $2 \mathrm{a}, \mathrm{b}$ and $\mathrm{c}$ ). The specimens subjected to wear show the wear mechanics during the back-and-forth sliding performed by the ball. This wear mechanism consists of the formation of an adhesive bond, its growth and subsequent fracture.

Nanoindentation analysis of UHMWPE shows the modulus of elasticity value for horizontal test with value of $950 \pm 61.4 \mathrm{MPa}$ and vertical of $936.4 \pm 53.3 \mathrm{MPa}$.

The specimen does not observe fatigue wear mechanism with the occurrence of micro-cracks even at the load greater than $30 \mathrm{~N}$ [8]. This is due to the mechanism by which a transfer layer is formed from the polymer to the metal that can have a self-lubricating effect. The results obtained from the UHMWPE subjected to wear test, surface characterization on wear tracks and nanoindentation tests provide information on the dry wear mechanism for possible biomedical and industrial applications.

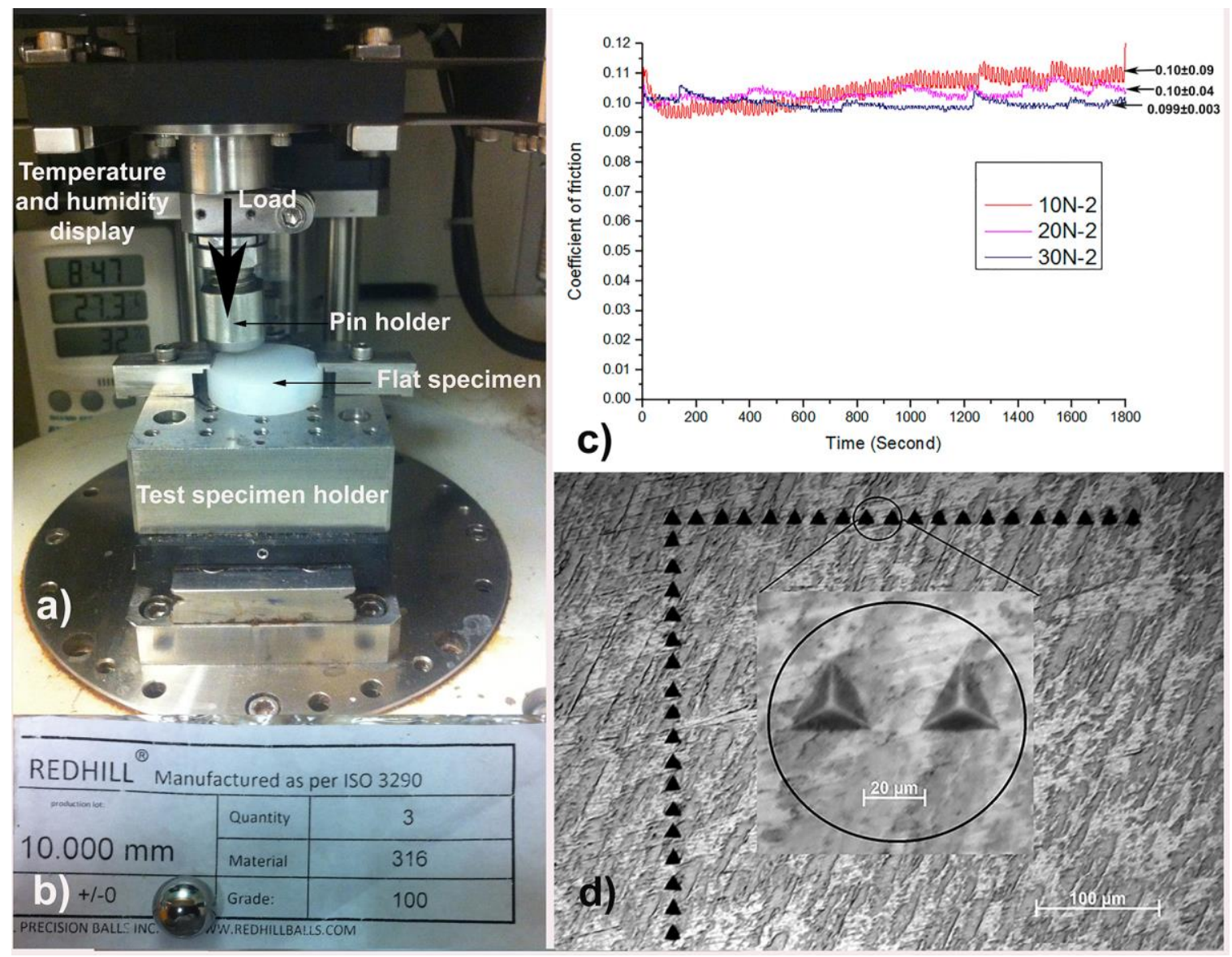


Figure 1. Reciprocating slip tests, a) CETR testing machine used with UHMWPE flat specimens, b) 316 steel ball, c) COF plot and c) nanoidentification tests to obtain the modulus of elasticity of the material.
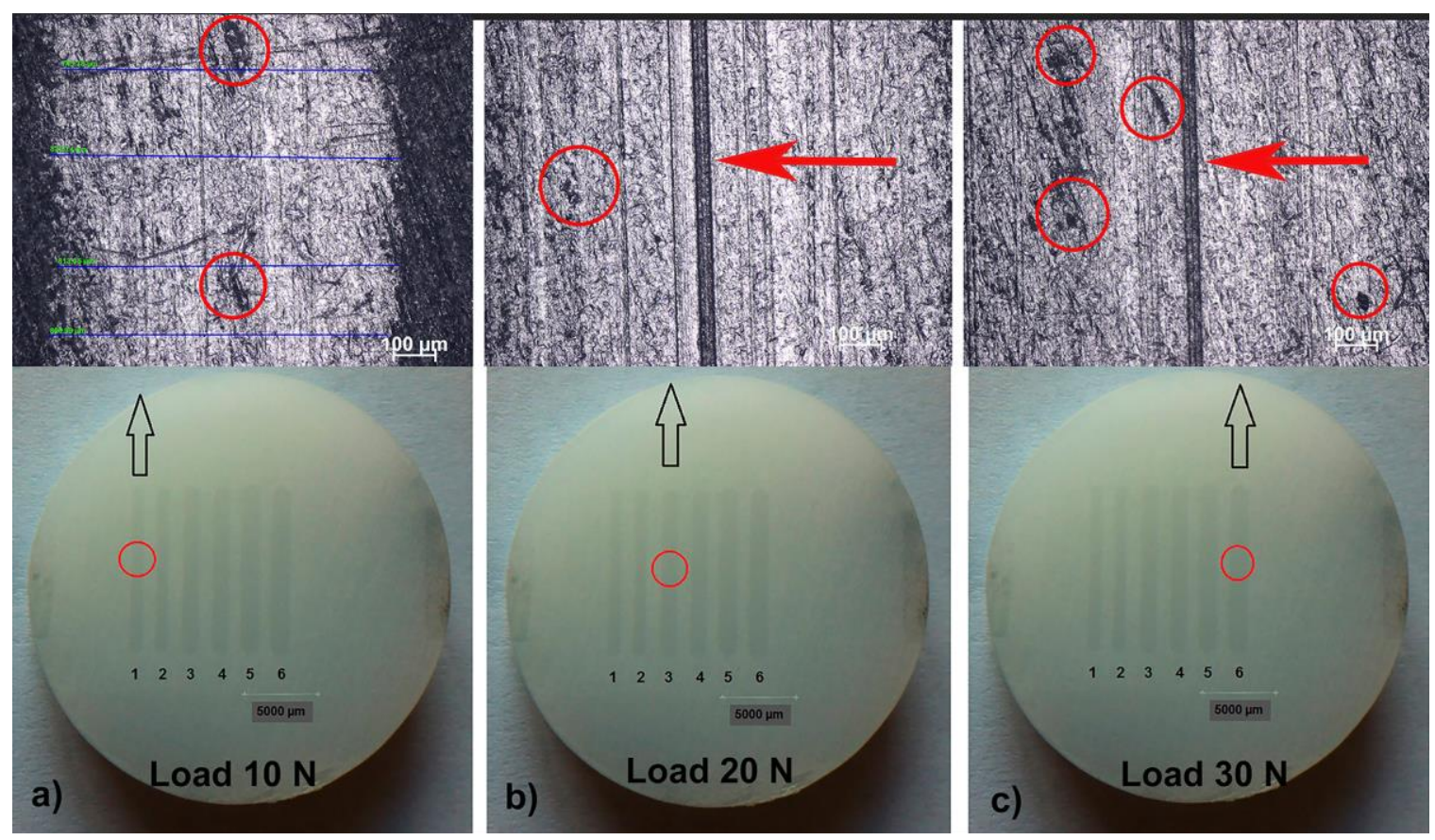

Figure 2. Optical micrographs of the wear track in planes at a) $10 \mathrm{~N}$, b) $20 \mathrm{~N}$ and c) $30 \mathrm{~N}$, conditions.

\section{References}

[1] T. De la Mora et al., "Numerical Model of Ultra-High Molecular Weight Polyethylene Abrasive Wear Tests.," Modeling and Numerical Simulation of Material Science, vol. 10, no. 1, pp. 40-53, January 2020. [2] ASTM G133, Standard test method for linearly Reciprocating ball on flat sliding wear. USA: ASTM, 2005.

[3] Gil y Ginebra, "Conceptos Básicos en Biomecánica, metales y aleaciones para la substitución de tejidos duros Biomecánica," Biomecánica, pp. 73-78, 2000.

[4] Zivic, "Interpretation of the Friction Coefficient During Reciprocating Sliding of Ti6Al4V Alloy Against Al2O3," Tribology in industry, pp. 36-42, 2011.

[5] R. Walter, "Comportamiento en desgaste deslizante de polietileno de alta densidad entrecruzado con radiación gamma," Revista Latinoamericana de Metalurgia y Materiales, pp. 112-23, 2012.

[6] FJ Buchanaan, "Micro-abrasion — a simple method to Micro-abrasion — a simple method to ageing.," Biomaterials, p. 93, 2002.

[7] Francisco Martínes Perez, La Ciencía y técnica para el mantenimiento. México: Limusa, 2002.

[8] J Cura, "PROPIEDADES TRIBOLÓGICAS Y NANOMECÁNICAS DE POLIETILENO DE ULTRA ALTO PESO MOLECULAR DE USO MÉDICO," Congreso SAM/CONAMET, pp. 1535-1540, 2007. 